\title{
Self- efficacy beliefs of pre-service teachers in teaching First Reading and Writing and Mathematics
}

\author{
Dilara Y1lmaz* \\ Kocaeli University Education Faculty, Kocaeli, Turkey, ORCID: 0000-0001-5539-8261
}

\begin{tabular}{|c|c|}
\hline \multicolumn{2}{|c|}{$\begin{array}{l}\text { Hakan Turan } \\
\text { Kocaeli University Education Faculty, Kocaeli, Turkey, ORCID: 0000-0002-8921-1917 } \\
\end{array}$} \\
\hline $\begin{array}{l}\text { Key words: } \\
\text { Self efficacy, First Reading } \\
\text { and Writing, Mathematics }\end{array}$ & $\begin{array}{l}\text { The aim of the study is to determine the relationship between primary } \\
\text { school pre-service teachers self-efficacy beliefs in teaching } \\
\text { Mathematics and First Reading and Writing courses. The sample } \\
\text { consists of } 4841 \text { st and 4th grade pre-service teachers selected from } \\
\text { four universities in Turkey. In the study, Mathematics and First } \\
\text { Reading and Writing Teaching Self-Efficacy Scale were used as data } \\
\text { collection tools. Besides descriptive statistical techniques, Independent } \\
\text { Sample T-test was used to determine whether the pre-service teachers' } \\
\text { self-efficacy beliefs differed according to some factors and Pearson } \\
\text { Product-Moment Correlation analysis was used to determine the } \\
\text { relationship between the pre-service teachers' beliefs in teaching Math } \\
\text { and First Reading and Writing. As a result of the research, it was found } \\
\text { that the levels of self-efficacy beliefs of the primary school pre-service } \\
\text { teachers in two courses were found to be high, that there was no } \\
\text { significant difference according to gender, that the self-efficacy beliefs } \\
\text { of the 4th grade pre-service teachers were higher in the Mathematics } \\
\text { teaching, and that the self-efficacy beliefs of the pre-service teachers } \\
\text { who chose the profession voluntarily were higher for teaching } \\
\text { Mathematics. It was also revealed that there was a moderate positive } \\
\text { relationship between self-efficacy beliefs of the pre-service teachers in } \\
\text { teaching for both courses. }\end{array}$ \\
\hline
\end{tabular}

\section{Introduction}

Self-efficacy is a concept that was made known by the psychological therapy studies conducted in the USA by Albert Bandura in 1970s. Bandura observed that while some individuals were adept at defeating their phobias, other individuals with the same characteristics had difficulty in defeating their phobias. Hence, it was noticed that there were factors such as self-perception and belief that affect individuals' desire to succeed (Sak1z, 2013). Albert Bandura (1994) describes self-efficacy as an individual's self-belief in performing a task or achieving a goal. According to Weinert (2001), self-efficacy is the motivational, voluntary and social readiness and capacity of individuals to use solutions successfully and responsibly in a variety of situations with the cognitive abilities and skills that individuals have or have learned to solve problems. 
Teacher self-efficacy beliefs are described as beliefs of the teachers in performing the necessary behaviors in order to fulfill the teaching task successfully. It is very likely that a teacher who has a developed self-efficacy belief can have students with improved selfefficacy beliefs. As a matter of fact, teachers with high self-efficacy beliefs provide more effective learning than others (Kaçar, 2016; İnel Ekici, 2018). The development of children's self-efficacy, especially during primary school, makes the issue even more important. This is because the education they receive during the primary school period can affect the future lives of these children. In sum, high self-efficacy beliefs in teachers can positively affect their students' self-efficacy beliefs.

Teaching efficacy is an important competence that impacts teachers' learning and teaching process. A primary school teacher may find themselves sufficient in one of the courses they teach and yet they may not find or see themselves that sufficient in some other courses. That is to say, a primary school teacher or prospective teacher who thinks he teaches Mathematics well might think that he cannot teach the First Reading and Writing lesson with the same efficacy. Tschannen-Moran and Woolfolk Hoy (2001) categorize teaching efficacy under three forms: teaching strategies, student participation and classroom management. Teaching strategies encompass the dimensions such as the teaching process, teaching methods, creating environments suitable for students according to individual differences and evaluating methods. Student participation is the effort of the teacher to ensure that the student becomes active through and throughout the course. To that end, self-efficacy of the teacher is important to ensure the active participation of the student. This is because student achievement increases or decreases proportionately according to teacher efficacy. In addition, the teacher's level of competence in this respect plays a role in shaping a student's attitude towards the school apart from contributing to his or her success level (Tschannen-Moran et al., 1998). Self-efficacy belief in view of classroom management has an overarching role of controlling student behaviors, ensuring that students comply with the rules, conducting activities in the classroom smoothly, creating an appropriate and effective classroom management system, and eliminating the problems that may arise in the classroom.

Primary education is an important period to constitute a ground for education in general and the majority of children reach literacy in this period (Üst, 2015). The First Reading and Writing education, being complex for the student, is also an important issue affecting his whole educational life. Students need a good teacher for primary reading instruction, as it is quite a complicated process. Thereupon, they should be taught by teachers who are qualified to teach reading and writing, and the level of knowledge, skills and competencies of the teachers should be complete (Güneş, Uysal \& Taç, 2016). Prospective primary school teachers are expected to have high self-efficacy and to develop themselves accordingly in order to complete their self-cultivation period in the desired way. There are many factors that influence the prospective teachers' perspectives on teaching First Reading and Writing. Belief in self-efficacy regarding this course is one of these factors. The high self-efficacy belief of the prospective teachers who are to start their professional life may affect both the perspectives and even the success of both the teacher and the students in the First Reading and Writing course. This is because the teacher, who is well aware of his or her strengths and weaknesses relating the course, can make the necessary corrections and ensure more effective teaching.

Teachers' belief in their own self and self-efficacy are related to many factors e.g. learning and teaching process, methods and strategies resorted to in class, classroom management and class participation (Ekin, 2018). Therefore, the teacher, who thinks that he or she is 
inadequate, is also likely to be incapable of transferring what he or she knows to the students (Değirmenci Gündoğmuş, 2017). In addition, as pre-service teachers' positive attitudes towards the First Reading and Writing teaching increase, their knowledge levels increase or the vice versa occurs (Üst, 2015). In the First Reading and Writing process, which is one of the most challenging stages during the learning phase, students are also affected by the attitudes and perceptions of teachers towards the lesson rather than the course itself (Bulut, 2017). In other words, teachers' self-efficacy beliefs can alter students' proficiency beliefs. Whereas students with low self-efficacy beliefs fail in the reading and writing process, others with high self-efficacy make more efforts and hence become more successful (Akar, 2008; Öztürk \& Ertem, 2017).

The efficient management of the learning process of reading and writing also contributes to the learning of other courses (Güneş et al. 2016). While students who do not have an effective First Reading and Writing education experience problems with comprehension and selfexpression in other courses, students who learn and use First Reading and Writing in a healthy way have lesser problems in other subjects (Özdemir, 2015: 22). Gaining reading and writing skills becomes more important as this affects students' daily life along with their academic life. The reason behind this is a student is deemed successful when he or she applies the outcome of the education received in his daily life. The reading and writing skills gained in primary school form the basis of all other courses and disciplines, hence they are a part of daily life. Thusly, good reading and writing skills are important and necessary both individually and socially.

As for Mathematics, it is a complex course that can cause anxiety when first encountered. According to Başpınar (2015), an individual's view of Mathematics is related to how he or she has learned Mathematics. Thus, first of all, a teacher teaching Mathematics should develop a positive attitude towards the lesson, for having a solid foundation in Mathematics, as in all other disciplines, paves the way for an individual's future life. According to Şallı (2012: 19), Mathematics education given in primary school is similar to the foundation of a building. Inadequate or incorrect Mathematics teaching in elementary school, similar to the problems of a building whose foundation is not firm, will bring some problems in the student's later life.

The aim of Mathematics teaching is to transfer Mathematical knowledge and skills to students in the most effective and efficient way. Effective Mathematics teaching depends on many factors such as students, teachers, programs, classroom climate and so on and they are actually the determinants of the quality of Mathematics teaching. Rich knowledge in Mathematics is needed for effective Mathematics teaching. Factors other than Mathematics are integrative, and the most important type of knowledge that complements the field knowledge is about knowing how to teach Mathematics (Turhan 2008). This is due to the fact that the methods and techniques referred to by teachers affect students' achievement in Mathematics alongside their attitude and self-efficacy beliefs (Dursun \& Dede 2004). Ünlü (2007) posits that the problems arising from the nature; innate complexity or abstractness of Mathematics, not carefully selected teaching strategies applied in the course of Mathematics and teachers' negative attitude and behavior while giving the course of Mathematics are main causes of Mathematics anxiety in students. Thence, teachers' beliefs in their efficacy interfere with student performance (Turanl1, Karakaş Türker \& Keçeli, 2008).

The most important platform where teachers gain and develop competence in Mathematics teaching is undergraduate programs. The aim of the undergraduate programs is to provide them with all the competencies and skills they need prior to graduation. Opinions on self 
efficacy of the prospective teachers about the courses they take during their undergraduate education vary (P1rasa, 2009). For example, a student in the first grade has less knowledge of Mathematics teaching than a student in the fourth grade, while the prospective teacher in the fourth grade has more information about the course itself. Hoşşirin Elmas (2010: 95) pinpoints that pre-service teachers have negative emotions like high level of anxiety, fear, and anxiety before taking Mathematics teaching course, but change their views on teaching Mathematics after taking that course. Negative emotions developed for the course mainly result from a lack of self-confidence, low self-efficacy belief and lack of field knowledge.

The institutions that train teachers should give importance to the practices and activities in teaching Mathematics and the course content should be related to daily life and they need cooperate with other institutions in this regard. In addition, so as to train teachers with high levels of self-efficacy, all factors affecting teacher competence should be taken into consideration and teacher training programs should be designed respectively (Bozkurt 2012: 20). The process of teacher training also includes the belief in self-efficacy. In the process of teacher education, self-efficacy of pre-service teachers should be developed together with the skills of Mathematical operations and problem solving (Ural, 2015).

According to some research on education that the pre-service teachers receive in undergraduate programs and on their performance in the field, the information learned in undergraduate education remained at the theoretical level, the training provided was insufficient and difficulties were experienced in implementation stages (Kartal, 2018; Karadağ \& Akkaya, 2013) owing to the lack of procedural knowledge. Even if the pre-service teachers take the First Reading and Writing course, they think that there are many deficiencies in the application of the course and that there is no integrity between practice and theory. Along these lines pre-service teachers feel inadequate (Yıldırım \& Demirtaş, 2008). According to Aytan (2017), prospective teachers hold the belief that the reading and writing teaching course is necessary, yet they are not interested enough due to the lack of theoretical and practical complement in the course. According to Kartal (2018), positive attitudes of the primary school pre-service teachers towards the course enhance as their level of success in that course increases. When research results are considered, it is expected that the programs of education faculties should be organized according to the skills and abilities that the teachers should acquire and become equipped with.

\section{Purpose}

First reading and writing and Mathematics, courses which are believed to be the most difficult ones for the primary teachers to handle and for the students to comprehend, are the subjects of this research. In the literature, there is a body of research on the self-efficacy in Mathematics and in First Reading and Writing courses howbeit no study is encountered in view of self-efficacy focusing on the relationship between these two courses which form the basis of classroom education. Then it would be fair to state that this makes this study unique and significant. In this regard, it is thought that the current study will contribute significantly to the literature.

The aim of the study is to specify both the relationship between the levels of self-efficacy beliefs of the first and fourth grade primary school Mathematic and First Reading and Writing pre-service teachers, and to find out if self-efficacy belief levels change according to some independent variables.

Answers to the following questions were searched for in line with this purpose: 
1. What is the level of pre-service teachers' self-efficacy beliefs in teaching First Reading and Writing, and Mathematics?

2. Is there any difference between the pre-service teachers' self-efficacy beliefs in teaching these two courses according to gender?

3. Is there any difference between the pre-service teachers' self-efficacy beliefs in teaching these two courses according to grade level?

4. Is there any difference between the pre-service teachers' self-efficacy beliefs in teaching these two courses according to their departmental preference?

5. Is there a relationship between the pre-service teachers' self-efficacy beliefs levels of these two courses?

\section{Methods}

\section{Research Design}

In this research, relational screening model was used to determine the relationships between the self-efficacy beliefs of primary school pre-service teachers. In relational screening model, the subject matter event or situation is examined as-is without any interventions. According to this model, the relationship or change levels between at least two variables are evaluated within their own conditions (Karasar, 2012).

\section{Participant}

While the universe of the study covers all the pre-service teachers of Kocaeli, Marmara, Sakarya, Uludağ and Yıldız Technical Universities, the sample consists of 484 preservice teachers from the first and fourth grades selected through criterion sampling which is amongst the purposeful sampling methods. The basic understanding of the criterion sampling method is to study all conditions that meet a predetermined number of criteria. (Y1ldirım \& Şimşek, 2016). Whether the pre-service teachers had taken "Mathematics Teaching" and "First Reading and Writing teaching" courses were taken as the criterion in this study. The reason behind choosing such a criterion was to determine whether the pre-service teachers' perceptions differed before and after taking these courses. A total of 510 data collection forms were used and 484 forms were evaluated after the incomplete or incorrectly filled forms were excluded from the analysis. Descriptive statistics of the prospective teachers are shown in Table1

Table 1: Demographics of the participants

\begin{tabular}{|c|c|c|c|}
\hline & Variables & $N$ & $\%$ \\
\hline \multirow{5}{*}{ 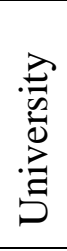 } & Kocaeli U. & 88 & 18 \\
\hline & Sakarya U. & 104 & 22 \\
\hline & Marmara U. & 100 & 21 \\
\hline & Yıldız Teknik U. & 69 & 14 \\
\hline & Uludağ U. & 123 & 25 \\
\hline \multirow{2}{*}{$\begin{array}{l}\overline{\vec{D}} \\
\bar{D} \\
0\end{array}$} & Female & 388 & 80 \\
\hline & Male & 96 & 20 \\
\hline \multirow{3}{*}{ 苟 } & First & 247 & 51 \\
\hline & Fourth & 237 & 49 \\
\hline & Total & 484 & 100 \\
\hline
\end{tabular}




\section{Materials}

As a data collection tool First Reading and Writing Teaching Self-Efficacy Scale (RWES) developed by Delican (2016) was made use of to determine the primary school preservice teachers' beliefs of competence, and for the self-efficacy belief in Mathematics, "Mathematics Teaching Efficacy Belief Instrument" developed by Enoch et al. (2000) was applied.

Self-Efficacy Scale formed by Delican (2016) was developed by applying it to 256 primary school pre-service teachers in 3rd and 4th grades. The 25-58, the 59-92, and the 93-125 point ranges from the scale represent low, medium and high self-efficacy beliefs, respectively. The form with the exploratory and confirmatory factor analysis explains $51.12 \%$ of the total variance. The reliability coefficient for the whole scale is .90 . The lowest score that can be gathered from the scale is 25 and the highest score is 125 . In the reliability analysis conducted on this research sample, alpha internal consistency coefficient is 0.94 .

The Scale for Mathematics Teaching Self-Efficacy developed by Enochs et al. (2000) consists of 21 items. The internal consistency coefficient of the original form was 0.88 and it was adapted to Turkish by Savran and Çakıroğlu (2001) for candidate Mathematics teachers. Afterwards, Hacıömeroğlu and Şahin-Taşkın (2010) carried out a study with the participation of 243 prospective primary school teachers for the confirmation of the factor analysis and announced that the scale had 3 factors. Cronbach's alpha internal consistency coefficient for the whole scale was determined to be 0.71 . The lowest score that can be obtained from the scale is 17 and the highest score is 85 . The $17-40$ points range from the scale represents low self-efficacy, the 41-62 points range represents medium and the 63-85 points range represents high self-efficacy. In the reliability analysis realized for this research sample, alpha internal consistency coefficient was calculated to be 0.80 .

\section{Data analysis}

In addition to descriptive statistical techniques, Independent Sample T-test was used to see whether the pre-service teachers' self-efficacy beliefs differed according to gender, departmental preference and grade levels, and Pearson's product moment correlation was used to determine if there is a relationship between the self-efficacy beliefs in the two courses. Levene value, which shows the homogeneity of variance and skewness and kurtosis, was used to specify whether the data indicated a normal distribution characteristics. Tabachnick and Fidell (2013: 79) underline that if the skewness and kurtosis values of these values are between +1.5 and -1.5 , an analysis is considered to be made according to the normal distribution. Skewness and kurtosis values of the mean scores obtained from the scales used in this study were found to be within the specified ranges (Skewness $=-.757,-.126$; Kurtosis $=1.068,-.537)$. Besides, according to Levene test results showing homogeneity of variances, the scales were found to be statistically appropriate $(\mathrm{F}=0.946,0.053, \mathrm{p}>.05)$. In light of those pieces of information, it can be shared that the mean scores obtained from each scale show normal distribution characteristics and they can be subjected to parametric tests. 


\section{Results}

\section{Findings regarding the first question}

The first question of the research is about the level of pre-service teachers' selfefficacy beliefs in teaching Math and First Reading and Writing and findings are given in Table 2.

Table 2. Descriptive Statistics

\begin{tabular}{lrrrrc}
\hline Self-Efficacy Beliefs & $N$ & Min & Max & $\bar{X}$ & SS \\
\hline First reading and writing & 484 & 29.00 & 125.00 & 96.81 & 15.49 \\
\hline Mathematics & 484 & 49.00 & 84.00 & 67.88 & 7.42 \\
\hline
\end{tabular}

According to Table 2, the participants have high self-efficacy beliefs in teaching reading and writing $(\overline{\mathrm{X}}=96.81)$ and Mathematics $(\overline{\mathrm{X}}=67.88)$.

\section{Findings regarding the second question}

The second question of the research is the difference in the self-efficacy beliefs of preservice teachers for two courses according to their genders and t-test results are presented in Table 3.

Table 3. T-Test Results according to the gender

\begin{tabular}{lllllrcc}
\hline Self-Efficacy Believes & Gender & \multicolumn{1}{c}{$N$} & \multicolumn{1}{c}{ X } & \multicolumn{1}{c}{ SS } & sd & \multicolumn{1}{c}{$t$} & \multicolumn{1}{c}{$\mathrm{p}$} \\
\hline First reading and writing & Female & 388 & 97.26 & 15.86 & 482 & 1.285 & .199 \\
& Male & 96 & 95.0 & 13.83 & & & \\
\hline Mathematics & Female & 388 & 68.18 & 7.20 & 482 & 1.781 & .076 \\
& Male & 96 & 66.67 & 8.18 & & & \\
\hline
\end{tabular}

As can be seen in Table 3, the participant's self-efficacy level of teaching Mathematics and First Reading and Writing did not significantly change according to gender $(t=1.285 ; t=1.781$; $\mathrm{p}>.05)$.

\section{Findings regarding the third question}

The third question of the research is the difference in the self-efficacy beliefs of preservice teachers for two courses according to their grade levels and t-test results are depicted in Table 4.

Table 4. T-Test Results according to grade levels

\begin{tabular}{llllllll}
\hline $\begin{array}{l}\text { Self-Efficacy } \\
\text { Believes }\end{array}$ & Grade & $N$ & $\bar{X}$ & SS & sd & $t$ & p \\
\hline $\begin{array}{l}\text { First reading and } \\
\text { writing }\end{array}$ & 1. & 247 & 92.98 & 17.21 & 482 & -5.739 & .000 \\
\hline Math teaching & 4. & 237 & 100.81 & 12.28 & & & \\
\hline
\end{tabular}

As displayed in Table 4, according to their grade levels, the participant's self-efficacy level of teaching First Reading and Writing $(\mathrm{t}=-5.739 ; \mathrm{p}<.05)$ significantly varied while their level for Mathematics teaching $(\mathrm{t}=0.393 ; \mathrm{p}>.05)$ did not. The fourth-grade pre-service teachers had a higher level of self-efficacy belief in First Reading and Writing $\left(\overline{\mathrm{X}}_{=}=100.81\right)$. 


\section{Findings regarding the fourth question}

The fourth question of the research is the difference in the self-efficacy beliefs of preservice teachers for two courses according to departmental preference and t-test results are provided in Table 5.

Table 5. T-Test Results according to departmental preference

\begin{tabular}{llllllll}
\hline $\begin{array}{l}\text { Self-Efficacy } \\
\text { Believes }\end{array}$ & Preference & $N$ & $\bar{X}$ & SS & sd & $t$ & $\mathrm{p}$ \\
\hline First reading and & Voluntarily & 292 & 97.40 & 16.10 & 482 & 1.083 & .279 \\
writing & Others & 191 & 95.84 & 14.50 & & & \\
\hline \multirow{2}{*}{ Mathematics } & Voluntarily & 292 & 68.82 & 7.33 & 482 & 3.503 & .001 \\
& Others & 192 & 66.43 & 7.35 & & & \\
\hline
\end{tabular}

As witnessed in Table 5, according to departmental preference prior to admission to the faculty, the participants' self-efficacy belief level for Mathematics $(t=3.503 ; \mathrm{p}<.05)$ significantly varied while it did not vary for First Reading and Writing $(t=1.083 ; p>.05)$. The participants who voluntarily chose their departments, at their own discretion, had higher level of self-efficacy belief in teaching Mathematics $(\overline{\mathrm{X}}=68.82)$.

\section{Findings regarding the fifth question}

The fifth question of the research is the relationship between pre-service teachers' self-efficacy beliefs in teaching in two courses and correlation results are displayed in Table 6.

Table 6. Correlation results

\begin{tabular}{llll}
\hline & & $\begin{array}{l}\text { Reading and Writing } \\
\text { teaching self-efficacy } \\
\text { belief }\end{array}$ & $\begin{array}{l}\text { Math teaching } \\
\text { efficacy belief }\end{array}$ \\
\hline $\begin{array}{l}\text { First reading and Writing } \\
\text { teaching self-efficacy belief }\end{array}$ & P. Corr. & 1 & $.39 * *$ \\
\hline $\begin{array}{l}\text { Mathematics teaching } \\
\text { efficacy belief }\end{array}$ & P. Corr. & & .00 \\
$\begin{array}{ll}* * \text { Correlation is significant at the } 0.01 \text { level. } & \text { Sig }\end{array}$ & 1 \\
\hline
\end{tabular}

As exhibted in Table 6, there is a positive and mid-level relationship ( $\mathrm{r}=.39, \mathrm{p}<.001)$ between the self-efficacy beliefs in Mathematics and First Reading and Writing teaching. According to Büyüköztürk (2016), if $r<.30$, there is a low relationship, if .30 $<r<.70$, there is a mid-level relationship and if $r>.70$, there is strong relationship between the 2 self-efficacy beliefs in these courses.

\section{Conclusion and discussion}

According to the findings related to the first question of the study, it was detected that the pre-service teachers had higher beliefs in teaching First Reading and Writing and Mathematics. Wherefore it can be said that prospective teachers consider themselves sufficient in teaching these courses. In the research conducted by Özdemir (2015) and Dedeli (2008) on the primary school pre-service teachers and in the studies conducted by Ekin 
(2018), and Öztürk and Ertem (2017) on primary school teachers, it was found that both preservice teachers' self-efficacy perceptions of First Reading and Writing teaching were quite high. In a study conducted by Haciömeroğlu (2013), it was found out that pre-service teachers had high self-efficacy beliefs about Mathematics teaching and in a study conducted by Jaggernauth (2010), it was concluded that Mathematics teaching self-efficacy beliefs of primary school teachers was high. All of these results in the related literature are consistent with the findings of this research.

According to the findings regarding the second question of the study, the mean scores of selfefficacy beliefs of primary school pre-service teachers for First Reading and Writing teaching and for Mathematics teaching did not show a significant difference according to gender. As a result, gender variable does not affect pre-service teachers' efficacy level for teaching Mathematics and for First Reading and Writing. Similarly, the results of the research conducted by Şallı (2012) and Hacıömeroğlu and Taşkın (2010) pointed also to the fact that there was no significant difference in the self-efficacy beliefs of candidate Mathematics teachers according to their gender. Also, both the research conducted by Ekin (2018) and the study carried out by Demirel and Akkoyunlu (2017), emphasized that the First Reading and Writing self-efficacy beliefs of the pre-service teachers did not disclose significant differences according to gender. These results of the relevant literature comply with the results of this research. As a result of the studies conducted by Değirmenci Gündoğmuş (2017), Öztürk and Ertem (2017), Özdemir (2015) and Dedeli (2008), it was figured out that the First Reading and Writing self-efficacy beliefs of pre-service teachers were significantly higher for female pre-service teachers than those of male candidates. These results differ from the results obtained in this study.

That the Women's self-efficacy beliefs are slightly higher might result from the fact that the majority of people preferring teaching profession are women in Turkey and they may tend to be more enthusiastic and professional in their jobs. Odanga, Raburu \& Aloka (2015) stated that female teachers have higher self-efficacy and they are more dedicated, even though teacher self-efficacy did not vary significantly by gender. Regarding the participants of that research, the female teachers pay close attention to their students. This situation underpins that female teachers are more prone to this profession than males.

As for the findings pertaining to the third question of the study, it was observed that the selfefficacy beliefs of the pre-service teachers for teaching First Reading and Writing showed a significant difference according to their grade levels and this difference was in favor of 4th grade pre-service teachers and that the self-efficacy beliefs in teaching Mathematics did not demonstrate significant difference according to grade levels. The reason why the First Reading and Writing self-efficacy beliefs were higher for the 4th grade pre-service teachers might be due to their taking First Reading and Writing teaching, Turkish teaching and other courses and learning them efficiently or because of developing positive attitudes towards the courses. It is also possible that school experience let them take teaching practice courses in real classroom environments which stimulated an increase in self-efficacy. That Mathematics teaching self-efficacy beliefs do not show significant differences in terms of grade levels may stem from the fact that Mathematics course can cause anxiety at all grade levels since the Mathematics teaching course taken in the undergraduate education for two semesters does not help develop sufficient awareness of the course. This may hinder the development of selfefficacy belief in the course and it may block the attainment of sufficient efficiency levels. The prospective teachers must have been positive about teaching First Reading and Writing in the courses where they could improve themselves through teaching practice or school 
experience and they might have developed a negative attitude towards Mathematics. The reason for that negative attitude for Mathematics is that primary school students are more unsuccessful in that course, and the pre-service teachers who observe these students also develop anxiety. According to PISA results conducted for 72 countries in 2015, the average Mathematics skills of Turkish students were 420 points and the average of reading skills is 428 points. According to PISA results in 2012, the average Mathematics skills of Turkish students were 448; The average reading skills were 475 points (PISA National Report). In consequence of the research conducted by Arseven et al. (2015), it was manifested that the candidate primary school teachers' perceptions of self-efficacy towards Mathematics teaching did not show significant differences according to grade levels. This result of the study is consistent with the results of this research. The research by Değirmenci Gündoğmuş (2017), Demirel and Akkoyunlu (2017) and Özdemir (2015) accentuate that there was no significant difference according to grade levels. These results differ from the results obtained in this study.

According to the findings obtained about the fourth question of the study, it was spotted that the self-efficacy beliefs of Mathematics teaching differed significantly with regard to the reason of the preference of the primary school teachers and this difference was in favor of the primary school pre-service teachers who preferred their department on their own. It was recognized that self-efficacy beliefs in First Reading and Writing teaching did not produce significant difference. Accordingly, it can be said that those who want to become a primary school teacher by their preference can teach better Mathematics and they see themselves more efficient in professional means. This finding reveals the fact that teaching Mathematics effectively or at least assuring self-confidence can only be possible with interest. The fact that the student has a lot of content knowledge about the lesson indicates that there is a lot of pedagogical content knowledge. Namely, content knowledge and pedagogical content knowledge go hand-in-hand each other (Mishra \& Koehler, 2005). In this case, it is assumed that the pre-service teachers who choose their profession and believe that they will perform in this profession have content knowledge of this course. For this reason, it is probable that the self-efficacy to teach this course is high. However, we could not find the same results for the First Reading and Writing teaching self-efficacy. The First Reading and Writing teaching is a planned and programmed process. The teaching of this course concerns only primary school teachers among all professional groups. Having said that it is not an effective factor for preservice teachers to choose their departments for it is usual that they do not have a positive or negative judgment of this course before university education. First Reading and Writing selfefficacy of the pre-service teachers who began university is low withal there is a sample study in the literature that their success is increased with trainings (Aydın \& Kartal, 2017).

According to the findings obtained from the fifth question of the study, there was a positive relationship between the self-efficacy levels for the First Reading and Writing and for Mathematics teaching. It can arguably be said that pre-service teachers who consider themselves sufficient in First Reading and Writing see themselves sufficient also in Mathematics. This finding could be explained with the success relationship between Mathematics and the First Reading and Writing course. There indeed is a strong relationship between reading and writing skills and math skills. It has been determined that students who have problems in reading and understanding are also less successful in Mathematics lessons (Tatar \& Soylu, 2006; Vilenius-Tuohimaa, Aunola \& Nurmi, 2008; Jordan et al., 2002; Jordan $\&$ Hanich, 2000). Likewise, it was found that there was a positive relationship between the teaching of these two courses. Accordingly, primary school pre-service teachers who believe that they can teach Mathematics effectively believe that they can also teach First Reading and 
Writing effectively as well.

As a result of the findings of the current research, these suggestions may be made: In the courses taken by the primary school pre-service teachers during their education period, attention should be paid to organizing activities to increase the interests and self-confidence levels of them especially by allocating more time and effort to practice in teaching Mathematics and First Reading and Writing courses. According to the results of the research, it can be said that the Mathematics teaching courses taken in the undergraduate period did not increase the pre-service teachers' beliefs and self-efficacy levels. Taking this into account, the content of the existing Mathematics and Mathematics teaching courses can be enrichened or the number of these courses can be augmented especially in order to obtain the required efficiency levels. Moreover, during the undergraduate education, prospective teachers' thoughts and attitudes about the courses can be monitored and they can further be trained by the expert educators at regular intervals. It is recommended that near future primary school teachers should be given some opportunity to enhance their preparation, implementation and evaluating in the process of improving their self-efficacy. We also strongly recommend that students should choose the profession that they genuinely want considering that fourth finding. Because it is difficult for people who do not choose their profession voluntarily to achieve the expected success or show positive attitudes as it is the case for the present research.

Also, introducing additional regulations so that increasing the self-confidence and selfefficacy beliefs of the teachers who are new to the profession can be a good alternative. Research can be carried out on larger samples with different methods on competency areas other than self-efficacy in teaching First Reading and Writing and Mathematics and as regards different branches and courses.

\section{Acknowledgement}

This study was produced from Dilara YILMAZ's Master Thesis titled Self-efficacy beliefs of primary school teacher candidates and self-efficacy belief in teaching first reading and writing and mathematics.

\section{References}

Akar, C. (2008). Self-efficacy beliefs and its effects of reading and writing. Usak University Journal of Social Science, 1(2), 185-198. Retrived from: https://dergipark.org.tr/tr/download/article-file/202459

Arseven, A., İ. Arseven \& Tepehan, T. (2015). Examination of class teacher candidates' mathematics teaching self-efficacy. Cumhuriyet International Journal of Education,4 (2), 29 - 40. Doi: 10.30703/cije.321367

Aydın, H. \& Kartal, H. (2017). Solving difficulties faced by classroom teachers in teaching literacy through in-service training. Academy Journal of educational Sciences, 1 (1), 34-54. DOI: $10.31805 /$ acjes.347649

Bandura, A. (1994). Self-efficacy. In V. S. Ramachaudran (Ed.), Encyclopedia of human Behavior, 4, 71-81.

Aytan, T. (2017). An analysis on the attitudes of classroom teacher candidates towards first reading and writing teaching course. Ahi Evran University Journal of Kirsehir Education Faculty, 18(2), 547-56. Doi: 10.5539/hes.v7n4p1 
Başpınar, K. (2015), Pre-service primary school teachers' mathematical beliefs and their mathematics teaching anxiety. (Unpublished Master Thesis). Afyon Kocatepe University Social Science Institution, Afyon.

Bozkurt, I. (2012). A comparison of elementary teachers' and teacher candidates' perceptions of their proficiency in teaching mathematics. (Unpublished Master Thesis). Erzincan University Primary mathematics Education, Erzincan.

Bulut, P. (2017). The effect of primary school students' writing attitudes and writing selfefficacy beliefs on their summary writing achievement. International Elecetronic Journal Elementary Education, 10 (2). 281-285. Doi: 10.26822/iejee.2017236123

Büyüköztürk, Ş. (2016). Sosyal bilimler için veri analizi el kitabı [Data analyse handbook for social science.] Ankara: Pegem.

Değirmenci Gündoğmuş, H. (2018). Self-Efficacy of teacher candidates for teaching fïst reading and writing. Educational Research and Reviews 13(6), 224-229. Doi: 10.5897/ERR2018.3486

Dedeli, S. (2008). The views of the senior class students of classroom teacher related to the level of the sufficiency in the prereading-writing teaching with the method of voice based sentence. (Unpublished Master Thesis). Dokuz Eylül University Educational Sciences Institution, İzmir.

Delican, B. (2016). The development of self-efficacy scale towards reading \& writing teaching. Turkish Studies International Periodical for The Languages, Literature and History of Turkish or Turkic, 11(3), 861-878.Doi: 10.7827/TurkishStudies.9277

Demirel, M. \& Akkoyunlu, B. (2017). Prospective teachers' lifelong learning tendencies and information literacy self-efficacy. Educational Research and Reviews, 12(6), 329-337. Doi: 10.5897/ERR2016.3119

Dursun, S., \& Dede, Y. (2004). The factors affecting students' success in mathematics: mathematics teachers' perspectives. Gazi University Journal of Gazi Educational Faculty, 24(2), 217-230. Retrived from: http://www.gefad.gazi.edu.tr/

Ekin, Ö. (2018). An investigation of classroom teachers' first reading and writing instruction self-efficacy perceptions in terms of various variables. (Unpublished Master Thesis). Cukurova University Social Science Institution, Adana.

Enochs, L. G., Smith P. L. \& Huinker, D. (2000). Establishing factorial validity of the mathematics teaching efficacy beliefs instrument. School Science and mathematics. 100, 194-202. Retrived from: https://onlinelibrary.wiley.com/doi/abs/10.1111/j.19498594.2000.tb17256.x

Güneş, F., Uysal, H. \& Taç, İ. (2016). The process of early reading and writing: My lecturer, can you teach me how to read and write? Journal of Education Theory and Practise, 2 (2), 23-33.

Hacıömeroğlu, G., \& Şahin Taşkın, Ç. (2010). Elementary preservice teachers' mathematics teaching efficacy belief. Journal of Uludag University Faculty of Education, 23 (2), 539-555. Retrived from: http://kutuphane.uludag.edu.tr/ Univder/uufader.htm

Hoşşirin Elmas, S. (2010). The pre-service primary school teachers' mathematics teaching anxiety levels and the reasons which cause this anxiety. (Unpublished Master Thesis). Afyon Kocatepe University Social Science Institution, Afyon.

Jaggernauth, S. J. (2010). Mathematics anxiety and the primary school teacher: An exploratory study of the relationship between mathematics anxiety, mathematics teacher efficacy, and mathematics avoidance. (Unpublished Master Thesis), The University of the West Indies Faculty of Humanities and Education, Jamaican. Retrived from: http://uwispace.sta.uwi.edu/dspace/bitstream/handle/2139/12548/ Sharon\%20Jaggernauth.pdf; sequence $=1$ 
Jordan, N.C., Kaplan, D. ve Hanich, L.B. 2002. Achievement growth in children with learning difficulties in mathematics: Finding of a two-year longitudinal study. Journal of Educational Psychology,94 (3), 586-597.

Jordan, N.C. ve Hanich, L.B. 2000. Mathematical thinking in second-grade children with different types of learning difficulties. Journal of Learning Disabilities, 33, 567-578.

Karadağ, R. \& Akkaya, A. (2013). Prospective teachers' opinions about microteaching applications on primary reading and writing course. Ahi Evran University Journal of Kirşehir Education Faculty, 14(2), 39-59. Retrived from: http://kefad.ahievran.edu.tr/

Karasar, Ni. (2012). Bilimsel araştırma yöntemi [Scientific research methods]. Ankara: Nobel Press.

Kartal, H. (2018). Factors Affecting preservice primary teachers' attitudes towards primary read and write teaching. Kastamonu Education Journal, 26(2), 509-521. doi:10.24106/kefdergi.389814

Kaçar, T. (2016). Analyzing of self-efficacy beliefs of elemantary school teachers. (Unpublished Master Thesis). Dokuz Eylül University Educational Sciences Institution, İzmir.

Mishra, P. ve Koehler, M.J. (2006). Technological pedagogical content knowledge: A framework for teacher knowledge. The Teachers College Record, 108(6), 1017-1054.

Odanga, S., Raburu, P. \& Aloka, S. (2015) Influence of gender on teachers' self-efficacy in secondary schools of kisumu county, Kenya. Academic Journal of Interdisciplinary Studies, 4 (3), 189-197. Doi: 10.5901/ajis.2015.v4n3p189

Özdemir, C. (2015). Determination to self-efficacy beliefs of primary education teacher candidates related to teaching of first reading and writing. (Unpublished Master Thesis), Karadeniz Technical University Institute of Educational Sciences. Trabzon.

Öztürk, B. \& Ertem, İ.S. (2017). Evaluation of primary school teachers' self-efficacy beliefs in teaching of emergent literacy. Journal of Anatolian Cultural Research, 1 (3), 1-26. Retrived from: http://ankad.org/InstitutionArchiveFiles/

Pirasa, N. (2009). Analysis of the change process of knowledge of teaching mathematics of preservice teachers. (Unpublished Doctoral Thesis). Trabzon Karadeniz Technical University Institute of Science.

PISA (2015) National Report Assesment. Retrived from:

http://pisa.meb.gov.tr/wp-content/uploads/2014/11/PISA2015_UlusalRapor.pdf

Sakız, G. (2013). Key word in success: Self-efficacy. Journal of Uludag University Faculty of Education, $26 \quad$ (1), 185-2009. Retrived from: http://www.acarindex.com/dosyalar/makale/acarindex-1423935263.pdf

Savran, A. \& Çakıroğlu, J. (2001). Preservice biology teachers' perceived efficacy beliefs in teaching biology. Hacettepe University Journal of Education, 21, 105-112. Retrived from: https://dergipark.org.tr/tr/download/article-file/87977

Şallı, F. (2012). Investigation of mathematical efficiency and mathematics teaching competencies of primary school teacher candidates. (Unpublished Master Thesis). İstanbul University Social Sciences Institution. İstanbul.

Tabachnick, B. \& Fidell, L. (2013). Using multivariate statistics. Nobel press.

Tatar, E. \& Soylu,Y. (2006). A study to determine effect of the achievement of readingcomprehension on the mathematics achievements. Kastamonu Education Journal, 14 (2), 503-508.

Tschannen-Moran, M., Woolfolk Hoy, A. \& Hoy, W. K. (1998). Teacher efficacy: Its meaning and measure. Review of Educational Research, 68 (2), 202-248. Doi: $10.1016 / \mathrm{s} 0742-051 \mathrm{x}(01) 00036-1$ 
Tschannen-Moran, M., \&; Woolfolk Hoy, A. (2001). Teacher efficacy: capturing and elusive construct. Teaching and Teacher Education, 17, 783-805. Doi: 10.1016/S0742051X(01)00036-1

Turanl1, N., Karakaş, N.T \& Keçeli, V. (2008). Developing an attitude scale for courses in mathematics, Hacettepe University Journal of Education, 34, 254-262. Retrived from: http://efdergi.hacettepe.edu.tr/yonetim/icerik/makaleler/525-published.pdf

Turhan, H.S. (2008). Examining the opinions of primary school 4 and 5th grade teachers about teaching mathematics course in terms of some variables (Unpublished Master Thesis). Gazi University, Social Sciences Institution, Ankara.

Ural, A. (2015). The Effect of mathematics self-efficacy on anxiety of teaching mathematics. Journal of Theoritical Educational Sciences, 8(2), 173-184. Doi:10.5578/keg.9075

Ünlü, E. (2007). The behaviour of the third, forth and fifth grade students towards mathematics and identifying their interests. Dumlupinar University Journal of Social Science, 19, 129-148. Retrived from: https://jestp.com/index.php/estp

Üst, E. (2015). A study on the knowledge levels and attitudes of department of primary school teaching fourth grade students about first reading and writing teaching. (Unpublished Master Thesis). Atatürk University Educational Sciences Institution, Erzurum.

Vilenius-Tuohimaa,P. M., Aunola,K. \& Nurmi, J.K. (2008) The association between mathematical word problems and reading comprehension, Educational Psychology, 28 (4), 409-426, DOI: 10.1080/01443410701708228

Yıldırım, A. \& Şimşek, H. (2016). Sosyal bilimlerde nitel araştırma yöntemleri. [Qualitative Research Methods In Social Sciences], Ankara: Seckin Press.

Yıldırım, N. \& Demirtaş, Z. (2008). Student views based a proposal for first reading and writing teaching course of classroom teaching department. Gaziantep University Journal of Social Sciences, 9(3), 681-695.

Y1lmaz, D. (2019). Primary school teacher candidates' teacher self efficacy beliefs and self efficacy beliefs in mathematics and first reading and writing. (Unpublished Master Thesis). Kocaeli University Social Sciences Institution, Kocaeli.

Weinert, F. E. (2001). Concept of competence: a conceptual clarification. in D. Rychen \& L. Salganik (Eds.), Defining and Selecting Key Competencies, 45-65. Retrived from: https://psycnet.apa.org/record/2001-05275-003 